\title{
ANIMAL MODELS OF DISEASE Classification and etiology of diabetes in dogs and cats
}

\section{Richard W Nelson and Claudia E Reusch'}

Department of Medicine and Epidemiology, School of Veterinary Medicine, University of California, Davis, California 95616, USA

${ }^{1}$ Clinic for Small Animal Internal Medicine, Vetsuisse Faculty, University of Zurich, Zurich, Switzerland
Correspondence should be addressed to R W Nelson

Email rwnelson@UCDAVIS.EDU

\begin{abstract}
Diabetes mellitus is a common disease in dogs and cats. The most common form of diabetes in dogs resembles type 1 diabetes in humans. Studies suggest that genetics, an immune-mediated component, and environmental factors are involved in the development of diabetes in dogs. A variant of gestational diabetes also occurs in dogs. The most common form of diabetes in cats resembles type 2 diabetes in humans. A major risk factor in cats is obesity. Obese cats have altered expression of several insulin signaling genes and glucose transporters and are leptin resistant. Cats also form amyloid deposits within the islets of the pancreas and develop glucotoxicity when exposed to prolonged hyperglycemia. This review will briefly summarize our current knowledge about the etiology of diabetes in dogs and cats and illustrate the similarities among dogs, cats, and humans.
\end{abstract}

\author{
Key Words \\ - diabetes \\ - islet cells \\ - autoimmune \\ - obesity \\ - insulin resistance
}

\section{Introduction}

Diabetes mellitus is a common disorder in dogs and cats, with a reported hospital prevalence rate of $\sim 0.4-1.2 \%$. Classic clinical signs of diabetes include polyuria, polydipsia, polyphagia, and weight loss. Clinical signs do not develop until hyperglycemia reaches a concentration that results in glycosuria, typically at blood glucose concentrations of $180-220 \mathrm{mg} / \mathrm{dl}$ in dogs and $220-270 \mathrm{mg} / \mathrm{dl}$ in cats. A subclinical or prediabetic state as occurs in humans is uncommonly recognized in dogs and cats. The diagnosis of diabetes is based on the presence of appropriate clinical signs and persistent hyperglycemia and glycosuria. Hypercholesterolemia and hypertriglyceridemia are common and ketonuria and ketoacidosis may develop if the owner fails to recognize early signs or is lax in seeking veterinary care. Treatment options are similar to those for human diabetics and include insulin injections (usually administered twice a day at $12 \mathrm{~h}$ intervals), dietary modifications, correction of obesity, exercise in dogs, and oral hypoglycemic medications in cats. The treatment approach differs between dogs and cats, in part, because the underlying etiology differs. Traditionally, the classification of diabetes mellitus in dogs and cats has more or less followed the scheme used in human medicine (American Diabetes Association (ADA) 2013). Although the etiopathogenic mechanisms may not be completely identical, the 'human model' provides a guide for identification and differentiation of the various forms of the disease in dogs and cats. Diabetes in dogs resembles type 1 diabetes in humans while diabetes in most cats resembles type 2 diabetes. This article focuses on our current understanding of the etiology of diabetes in dogs vs cats and illustrates the similarities among dogs, cats, and humans.

Published by Bioscientifica Ltd.

This paper forms part of a thematic review series on Animal Models of Disease. The Guest Editor for this section was Alan Conley University of California att/Q2avis_. Bavis $2: 17: 08 \mathrm{PM}$ CA, USA. 


\section{Type 1 diabetes mellitus: dogs}

The most common clinically recognized form of diabetes mellitus in the dog resembles type 1 diabetes mellitus in humans and is characterized by permanent hypoinsulinemia, essentially no increase in endogenous serum insulin or C-peptide concentrations following administration of an insulin secretagogue (e.g., glucose, glucagon, and amino acids), and an absolute necessity for exogenous insulin to maintain control of glycemia, avoid ketoacidosis, and survive (Montgomery et al. 1996). Virtually all dogs are insulin dependent at the time when diabetes mellitus is diagnosed. Common histological abnormalities in dogs include a reduction in the number and size of pancreatic islets, a decrease in the number of $\beta$-cells within islets, and $\beta$-cell vacuolation and degeneration. An extreme form of the disease may occur in juvenile dogs, represented by an absolute deficiency of $\beta$-cells and pancreatic islet hypoplasia or aplasia. Less severe changes involving the pancreatic islets and $\beta$-cells may predispose the adult dog to diabetes mellitus after the dog has been exposed to environmental factors, such as insulinantagonistic diseases and drugs, and pancreatitis.

The etiology of type 1 diabetes in dogs is undoubtedly multifactorial (Table 1). Genetic predispositions have been suggested by familial associations, pedigree analysis of Keeshonds, and genomic studies aimed at identification of susceptibility and protective major histocompatibility complex haplotypes (Table 2; Guptill et al. 2003, Kennedy et al. 2006, Fall et al. 2007). A number of genes linked with susceptibility to diabetes in humans are associated with an

Table 1 Potential factors involved in the etiopathogenesis of diabetes mellitus in dogs and cats

\begin{tabular}{l}
\hline Dog \\
\hline Genetics \\
Immune-mediated insulitis \\
Pancreatitis \\
Obesity \\
Concurrent hormonal disease \\
Hyperadrenocorticism \\
Diestrus-induced excess \\
growth hormone \\
Hyperthyroidism \\
Drugs \\
Glucocorticoids \\
Progestogens \\
Infection \\
Concurrent illness \\
Kidney disease \\
Cardiac disease \\
Hyperlipidemia
\end{tabular}

Cat

Islet amyloidosis

Obesity

Pancreatitis

Concurrent hormonal disease Hyperadrenocorticism Acromegaly Hyperthyroidism Drugs

Progestogens

Glucocorticoids

Infection

Concurrent illness

Kidney disease

Cardiac disease

Hyperlipidemia (?)

Genetics (Burmese cat)

Immune-mediated insulitis (?)
Table 2 Breeds with a significantly $(P<0.05)$ decreased or increased risk of diabetes mellitus (Veterinary Medical Data Base, 1970-1999) ${ }^{\mathrm{a}}$

\begin{tabular}{|c|c|c|c|}
\hline Breed & Cases & Control & Odds ratio \\
\hline Australian terrier & 37 & 1 & 32.10 \\
\hline Standard schnauzer & 105 & 19 & 4.78 \\
\hline Samoyed & 175 & 45 & 3.36 \\
\hline Miniature schnauzer & 624 & 172 & 3.13 \\
\hline Fox terrier & 91 & 26 & 3.02 \\
\hline Keeshond & 57 & 20 & 2.45 \\
\hline Bichon frise & 50 & 18 & 2.40 \\
\hline Finnish spitz & 35 & 13 & 2.32 \\
\hline Cairn terrier & 67 & 28 & 2.07 \\
\hline Miniature poodle & 737 & 356 & 1.79 \\
\hline Siberian husky & 80 & 45 & 1.53 \\
\hline Toy poodle & 208 & 139 & 1.29 \\
\hline Mixed breed & 1860 & 1609 & $\begin{array}{c}1.00 \\
\text { (Reference) }\end{array}$ \\
\hline Beagle & 73 & 94 & 0.67 \\
\hline English setter & 30 & 42 & 0.61 \\
\hline Labrador retriever & 246 & 364 & 0.58 \\
\hline Basset hound & 33 & 50 & 0.57 \\
\hline Dalmatian & 28 & 45 & 0.53 \\
\hline Doberman pinscher & 109 & 182 & 0.51 \\
\hline Irish setter & 68 & 121 & 0.48 \\
\hline Boston terrier & 31 & 68 & 0.39 \\
\hline Shih tzu & 31 & 69 & 0.38 \\
\hline Brittany & 28 & 64 & 0.37 \\
\hline Old english sheepdog & 14 & 35 & 0.35 \\
\hline Norwegian elkhound & 10 & 26 & 0.33 \\
\hline Golden retriever & 108 & 294 & 0.31 \\
\hline English pointer & 11 & 36 & 0.26 \\
\hline Cocker spaniel & 90 & 307 & 0.25 \\
\hline Great dane & 15 & 54 & 0.24 \\
\hline Bulldog & 7 & 26 & 0.23 \\
\hline Shetland sheepdog & 29 & 107 & 0.23 \\
\hline Collie & 25 & 109 & 0.19 \\
\hline Pekingese & 14 & 66 & 0.18 \\
\hline German shepherd & 70 & 365 & 0.16 \\
\hline Airedale terrier & 8 & 45 & 0.15 \\
\hline $\begin{array}{l}\text { German shorthaired } \\
\text { pointer }\end{array}$ & 6 & 37 & 0.14 \\
\hline Boxer & 7 & 82 & 0.07 \\
\hline
\end{tabular}

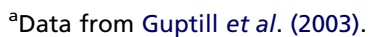

increased risk of diabetes in dogs (Catchpole et al. 2013). Diabetes in dogs has been associated with major histocompatibility complex class II genes (dog leukocyte antigen $(D L A)$ ), with similar haplotypes and genotypes being identified in the most susceptible breeds. A region containing a variable number of tandem repeats and several polymorphisms has been identified in the canine insulin gene, with some alleles associated with susceptibility or resistance to diabetes in a breed-specific manner (Catchpole et al. 2013).

Studies suggest an immune-mediated component in the development of diabetes in some dogs. Immunemediated insulitis characterized by infiltration of

Published by Bioscientifica Ltd http://joe.endocrinology-journals.org DOI: 10.1530/JOE-14-0202
๑) 2014 Society for Endocrinology Printed in Great Britain 
lymphocytes into the islets has been described and antibodies directed against islet cells, insulin, proinsulin, intracellular glutamic acid decarboxylase 65 (GAD65), and insulinoma antigen 2 (IA2) have been identified in diabetic dogs (Hoenig \& Dawe 1992, Davison et al. 2003, $2008,2011)$. The presence of circulating autoantibodies against insulin, proinsulin, GAD65, and IA2 usually precedes the development of hyperglycemia or clinical signs in humans with type 1 diabetes. A similar sequence of events may also occur in dogs although the onset of type 1 diabetes typically occurs in dogs that are at 8 years of age or older. Canine diabetes appears to more closely resemble latent autoimmune diabetes of adult humans (Andersen et al. 2010). Seemingly, autoimmune mechanisms, in conjunction with genetic and environmental factors, insulin-antagonistic diseases and drugs, and pancreatitis all play a potential role in the initiation and progression of diabetes in dogs. The end result is a loss of $\beta$-cell function, hypoinsulinemia, impaired transport of circulating glucose into most cells, accelerated hepatic gluconeogenesis and glycogenolysis, and the subsequent development of hyperglycemia and glycosuria. Loss of $\beta$-cell function is irreversible in dogs with type 1 diabetes and lifelong insulin therapy is mandatory to maintain glycemic control of the diabetic state.

\section{Type 1 diabetes mellitus: cats}

In contrast to the dog, type 1 diabetes is considered rare in cats. Lymphocytic infiltration into the islets (insulitis) as a marker of immune-mediated disease has only been described in a few cats (Minkus et al. 1991, Hall et al. 1997). In a recent study examining islet lesions in a larger group of diabetic cats against a control population (matched in age, sex, and body weight), a tendency of lymphocytes to be more frequent in diabetic cats was found $(20 \%$ of diabetic cats vs $5 \%$ of control cats), but the infiltration was usually mild and may reflect an inflammatory situation also known to be present in type 2 diabetes (Zini et al. 2012). Only one of the 27 diabetic cats had severe lymphocytic infiltration, which was similar in severity to those described in the two studies mentioned above (Fig. 1). $\beta$ cell and insulin antibodies have so far not been demonstrated in newly diagnosed diabetic cats (Hoenig et al. 2000).

\section{Type 2 diabetes mellitus: cats}

Approximately $80 \%$ of diabetic cats suffer from a type 2like diabetes mellitus that is a heterogeneous disease attributable to a combination of impaired insulin action in liver, muscle, and adipose tissue (insulin resistance), and

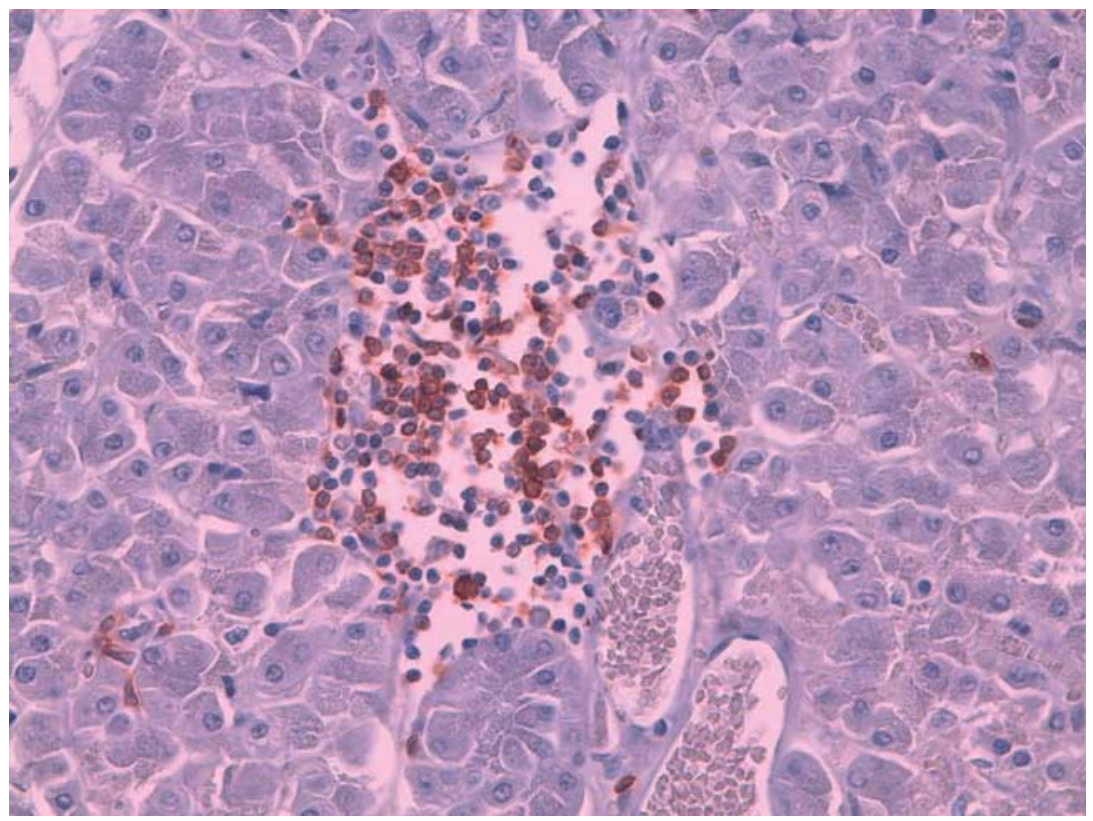

Figure 1

Pancreatic histology. Severe infiltrations with T lymphocytes within a pancreatic islet in an 18-year-old DSH cat with diabetes mellitus. This is a rare finding, usually only few or no lymphocytes are
C 2014 Society for Endocrinology Printed in Great Britain found in islets of diabetic cats. Immunohistochemistry for CD3, HE counterstain $(\times 40)$.

Published by Bioscientifica Ltd 
$\beta$-cell failure. Environmental as well as genetic factors are thought to play a role in the development of both defects. Genetic factors have just started to be investigated in the cat (Forcada et al. 2014). It is likely that diabetes in the cat is a polygenic disease and that many genes will be associated with an increased risk for the disease. The most convincing evidence of a genetic basis comes from studies in the Burmese cat. In breeding lines from Australia, New Zealand, and the United Kingdom, the frequency of diabetes was shown to be approximately four times higher in Burmese cats than in domestic cats and in some families of Burmese cats more than $10 \%$ of the offspring were affected by diabetes (McCann et al. 2007, Lederer et al. 2009).

One of the major risk factors for the development of diabetes in cats is obesity. Others include sex (males higher risk than females), physical inactivity and indoor confinement, increasing age, and the administration of glucocorticoids and progestins (Panciera et al. 1990, McCann et al. 2007, Prahl et al. 2007, Slingerland et al. 2009). It has been shown that obese cats are 3.9 times more likely to develop diabetes mellitus compared with cats with an optimal body weight (Scarlett \& Donoghue 1998). Experimental studies in healthy cats showed that an average weight gain of $1.9 \mathrm{~kg}$ during a feeding trial was associated with a decrease in insulin sensitivity of more than 50\% (Appleton et al. 2001). Similar results were reported in another trial in which each kilogram increase in weight led to $\sim 30 \%$ loss in insulin sensitivity (Hoenig et al. 2007). Insulin sensitivity differs considerably between individuals and it has been suggested that cats with intrinsically low insulin sensitivity are at an increased risk of developing glucose intolerance with weight gain. Male cats tended to have lower insulin sensitivity before the feeding trial and gained more weight than female cats, which might explain in part why male cats are at an increased risk of developing diabetes mellitus (Appleton et al. 2001). The effect of sex steroids on differences in insulin sensitivity and weight gain in male vs female cats has not been reported.

The mechanisms of insulin resistance on a cellular level and the interrelations of the different findings are not yet understood in cats. Most of the research to date has focused on glucose transporters, insulin signaling genes in insulinsensitive tissues, and secretion of adipocytokines from adipose tissue. In cats that became obese, the expression of the insulin-sensitive glucose transporter GLUT4 (SLC2A4) in muscle and fat was significantly lower than that in lean cats, whereas the expression of GLUT1 (SLC2A1), which is not insulin sensitive, remained unchanged (Brennan et al.
2004). Expression of several insulin signaling genes in liver and skeletal muscles was significantly lower in obese cats than in lean cats, which is similar in humans with insulin resistance (Mori et al. 2009). Also similar to humans, it is now recognized in cats that adipose tissue is an active and complex endocrine organ. Adiponectin, which is almost exclusively produced in adipose tissue, decreases with obesity and diabetes mellitus in cats (Hoenig et al. 2007). Adiponectin enhances insulin sensitivity and has antiinflammatory properties; a decrease, therefore, contributes to insulin resistance and inflammation. Leptin, the 'prototypic' adipokine, is involved in appetite suppression and energy expenditure and plays a role in modulation of insulin sensitivity (Radin et al. 2009). Obese cats have been found to be leptin resistant, i.e., they have much higher leptin concentrations than lean cats without causing an appropriate physiological response (Hoenig 2012). Adipose tissue secretes a number of proinflammatory cytokines and obesity is now considered a state of low-grade chronic inflammation. TNF $\alpha$ was the first adipose-derived factor suggested to represent a link between obesity and the insulin resistance observed in human type 2 diabetes; this cytokine exerts a strong negative influence on insulin signaling. Today, various additional cytokines and chemokines (e.g., IL6 and MCP1) are also known to be involved in the inflammatory process in humans. Adipose tissue in cats may behave in a similar manner, as the level of TNF $\alpha$ (in fat) was significantly higher in obese cats than in lean cats (Hoenig et al. 2006).

Insulin resistance evolving during weight gain is reversible after weight loss. When healthy cats were fed ad libitum, weight gain was associated with a significant increase in glucose and insulin concentrations during an intravenous glucose tolerance test (IVGTT) compared with baseline and the total amount of insulin secretion was significantly higher. Several weeks after achieving weight loss by intake of low-calorie diets, the results of the IVGTT were similar to those at baseline (Biourge et al. 1997, Fig. 2).

Although obesity induces insulin resistance, not all obese cats develop diabetes mellitus. Presumably for diabetes to develop, there must be $\beta$-cell dysfunction leading to impaired glucose tolerance and eventually type 2 diabetes. Unfortunately, there is minimal information on $\beta$-cell function and insulin secretion in cats during the natural development of diabetes. Most studies have been conducted on healthy cats in which obesity was induced within a short period of time by feeding ad libitum.

One hypothesis to explain the loss of $\beta$-cell function in type 2 diabetes involves $\beta$-cell destruction by amyloid

Published by Bioscientifica Ltd 

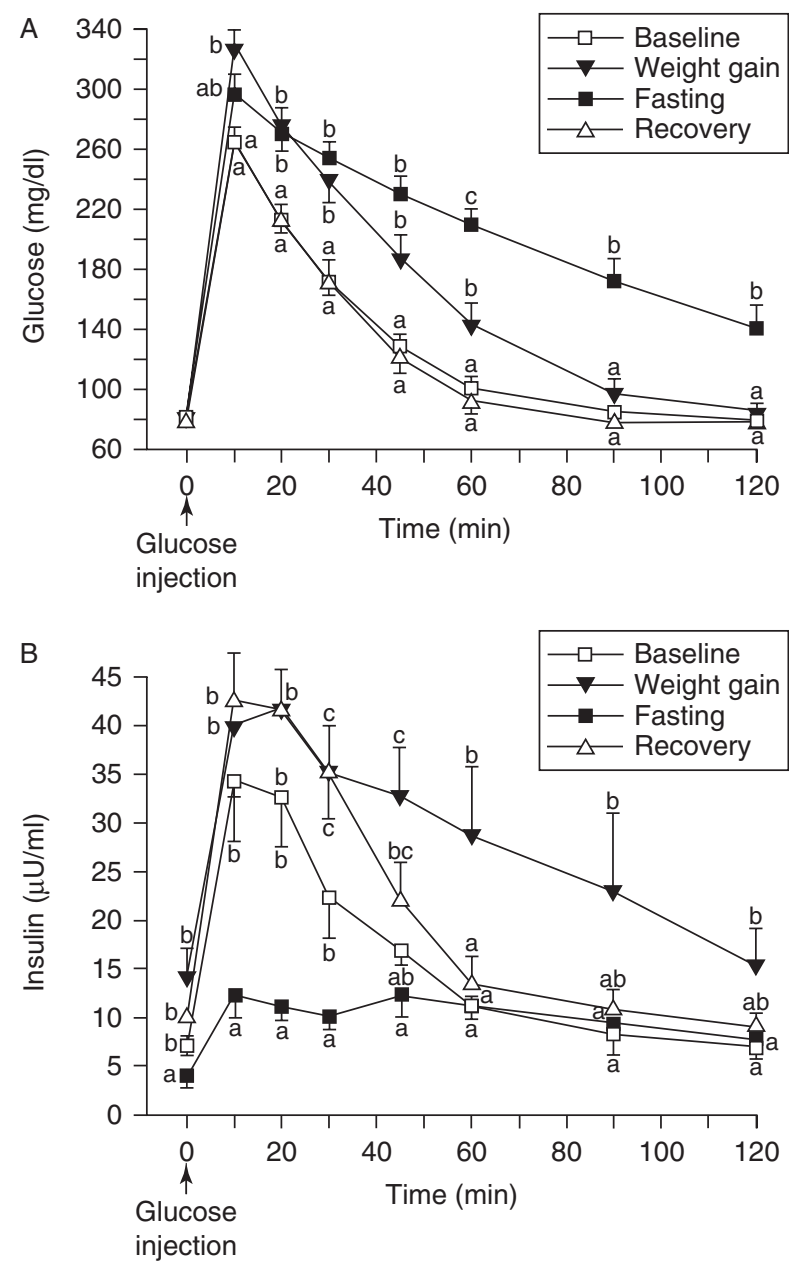

Figure 2

Mean serum glucose (A) and insulin (B) concentrations ( \pm s.E.M.) in 12 cats after i.v. administration of $0.5 \mathrm{~g}$ glucose $/ \mathrm{kg}$ of body weight at entry into the study (baseline), after $9 \pm 2$ months of weight gain, after a voluntary fast of 5-6 weeks (weight loss), and 5 weeks after the end of fasting (recovery). a-c: points with a different letter are significantly different $(P<0.05)$ among periods. Note the development of impaired glucose tolerance despite increased insulin secretion with weight gain and improvement in glucose tolerance and the exaggerated insulin secretory response with weight loss. Reproduced, with permission, from Biourge et al. (1997).

deposition. Islet amyloid is derived from a hormone named islet amyloid polypeptide (IAPP) also known as amylin. IAPP is a normal product of the $\beta$-cells, is stored with insulin in secretory vesicles, and is co-secreted with insulin into the circulation. IAPP levels are elevated in conditions associated with insulin resistance, e.g., in cats with obesity (Henson et al. 2011). Cats, humans, and nonhuman primates have an amyloidogenic amino acid structure of IAPP with the potential to form amyloid depositions within the islets of the pancreas (O'Brien 2002, Hull et al. 2004). Islet amyloid deposits have not been identified in hamsters, rats, mice, or dogs while IAPP and amyloid deposits have been identified in canine endocrine tumors (Jordan et al. 1990, O'Brien et al. 1990). Amyloid depositions have been found in many cats with diabetes but are also a frequent finding in nondiabetic cats. In a recent study, $56 \%$ of diabetic cats and $42 \%$ of control cats matched for age, sex, and body weight had amyloid depositions, the amount of which was also comparable (Zini et al. 2012; Fig. 3). It is not known as to why some but not all diabetic cats develop amyloid deposits and whether amyloid is a cause or consequence of the disease. Disturbed protein folding and/or trafficking of amylin within the $\beta$-cell lead to the formation of toxic oligomers. These intracellular molecules induce cytotoxicity and may lead to a decline in $\beta$-cell function and to $\beta$-cell apoptosis. The extracellular amyloid deposits seem to be less toxic and represent the end point of misfolding (Costes et al. 2013). Loss of $\beta$-cell function may be present before amyloid depositions are visible. Misfolding may be a reflection of another defect within the $\beta$-cell and not the primary cause of $\beta$-cell dysfunction. When present, however, these abnormalities may accelerate further damage.

Hyperglycemia is an additional factor, which has a negative impact on $\beta$-cell function and survival in cats, a phenomenon known as glucotoxicity (Link et al. 2013). There is little doubt whether glucotoxicity is a secondary event, as hyperglycemia becomes apparent only after $\beta$-cells start to fail. However, improving glycemic control by insulin therapy will reverse some of the negative effects of glucotoxicity and reversal of glucotoxicity is an important mechanism to explain diabetic remission in cats (Nelson et al. 1999). The cellular mechanisms through which chronic hyperglycemia affects insulin secretion and insulin sensitivity are poorly understood. In humans, it has been proposed that oxidative stress and inflammatory cytokines play an important role (Robertson 2009, Donath $\&$ Shoelson 2011). In a recent study, glucose-induced lesions in $\beta$-cells were investigated in cats (Zini et al. 2009). After 10 days of i.v. glucose infusion, healthy cats had $50 \%$ fewer $\beta$-cells per islet area than healthy control cats that were not infused. Islet cells showed apoptotic features and were caspase 3 (a marker for apoptosis) positive (Fig. 4). Interestingly, hyperglycemia induced a systemic inflammatory response, characterized by an increased plasma concentration of $\alpha 1$-acid glycoprotein. Systemic inflammation has also been described in human type 2 diabetes.

Lipotoxicity is the term used for the deleterious effect of high circulating concentrations of free fatty acids on $\beta$-cell function. Lipotoxicity may not be as important as glucotoxicity in cats (Zini et al. 2009). In

Published by Bioscientifica Ltd 


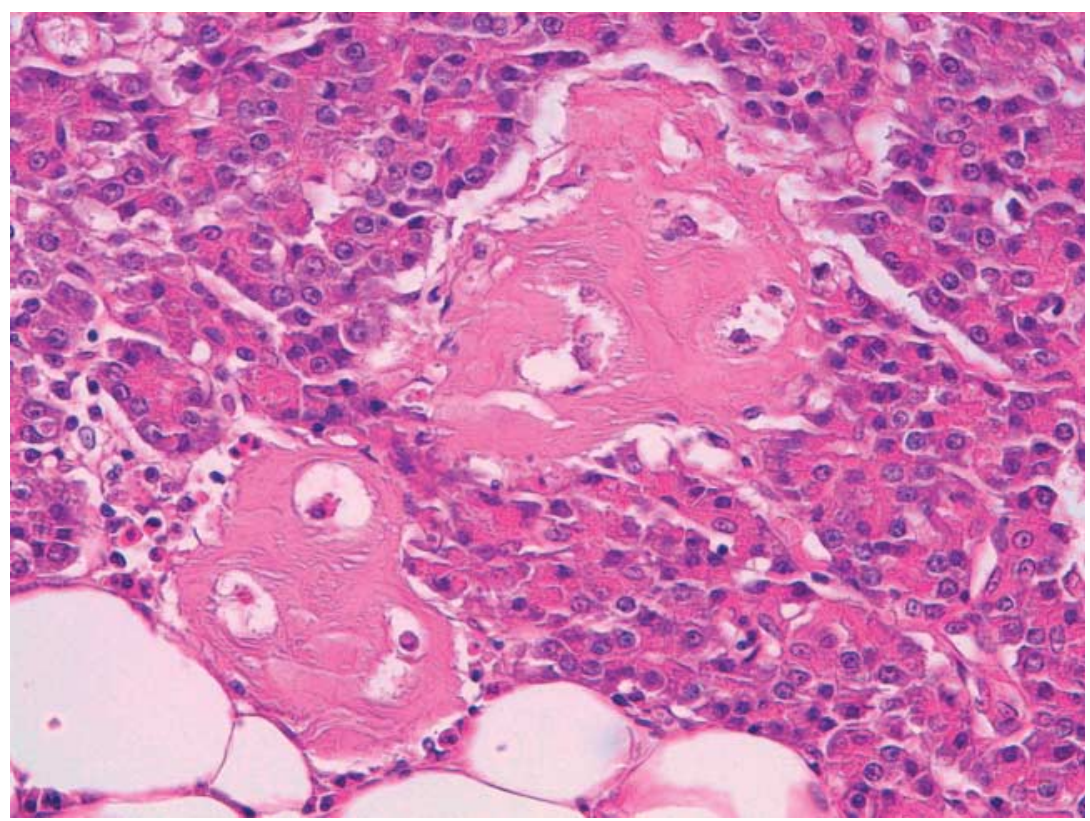

\section{Figure 3}

Pancreatic histology. Islet amyloidosis in a 16-year-old female spayed DSH cat with diabetes mellitus $(H \& E, \times 40)$.

contrast to the deleterious impact of a 10-day glucose infusion on $\beta$-cells, lipid infusion over the same time period did not affect plasma insulin or glucose concentrations or results in $\beta$-cell apoptosis. In human medicine, it has been proposed that glucotoxicity occurs independent of lipotoxicity, whereas lipotoxicity requires increased blood glucose levels to fully manifest. This may also apply to cats.

\section{Type 2 diabetes mellitus: dogs}

Obesity-induced insulin resistance has been documented in dogs but progression to type 2 diabetes does not occur (Verkest et al. 2012). Studies suggest that at least some of the etiopathogenic mechanisms responsible for the development of obesity-associated type 2 diabetes in humans and cats do not occur in dogs. For example, $\beta$-cell sensitivity to changes in glucose and the first phase of the insulin secretory response by the $\beta$-cell are lost in humans and cats but not in dogs despite years of obesityinduced insulin resistance and compensatory hyperinsulinemia (Verkest et al. 2011a). In humans, loss of the first phase of insulin secretion is an important early marker of $\beta$-cell failure (Gerich 2002).

IAPP forms toxic intracellular oligomers in $\beta$-cells in humans and cats but not in dogs and amylin does not aggregate extracellularly as histologically visible amyloid in the pancreatic islets in dogs (Haataja et al. 2008, Scheuner \& Kaufman 2008). Circulating concentrations of the adipocyte-secreted hormone adiponectin are

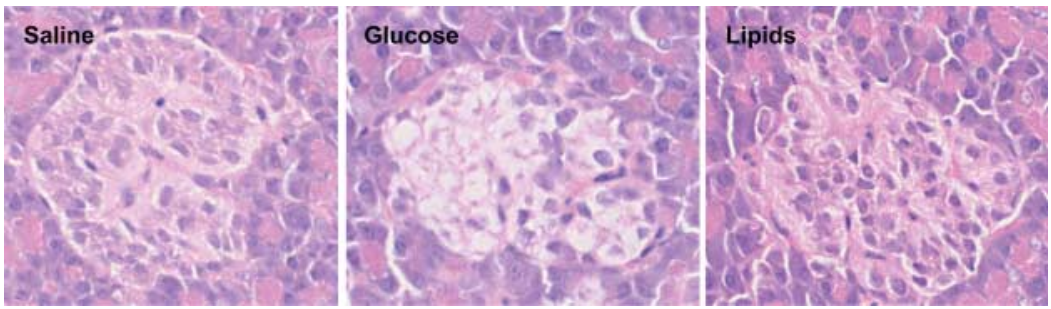

\section{Figure 4}

Pancreatic islets of healthy cats after receiving $0.9 \% \mathrm{NaCl}$, i.v. glucose infusion, and intravenous lipids for 10 days. No lesions were observed in the control cat and in the cat that received lipids. In the glucose-infused cat, a large area of the islet appeared devoid of nuclei and included several vacuoles, suggesting
(C) 2014 Society for Endocrinology Printed in Great Britain hydropic degeneration. Hydropic degeneration of islet cells indicates the accumulation of glycogen. The remaining islet nuclei appear larger than that in the control cat. (H \& E, ×40). Reproduced from Zini et al. (2009), with kind permission from Springer Science and Business Media. 
decreased in obese humans and low adiponectin concentrations predict progression to type 2 diabetes in humans (Li et al. 2009). By contrast, circulating adiponectin concentrations were not lower in chronically obese dogs, compared with lean dogs, and adiponectin was not associated with insulin sensitivity in obese dogs (Verkest et al. 2011b). Although adiponectin does not appear to play a role in the development of canine obesityassociated insulin resistance, adiponectin receptors are present on pancreatic $\beta$-cells and adiponectin has been shown to protect $\beta$-cells against fatty acid-induced apoptosis (Kharroubi et al. 2003, Rakatzi et al. 2004).

\section{Other specific types of diabetes: dogs and cats}

The category 'other specific types' refers to diabetes that develops in association with diseases or factors other than those described under type 1 or type 2 diabetes mellitus. A large number of genetic syndromes are listed in this category for humans but similar syndromes have not been described in dogs or cats. Diabetes may occur secondary to disorders of the exocrine pancreas and any process that diffusely injures the pancreas can cause diabetes, most notably pancreatitis. The incidence of histologically identifiable often severe pancreatitis in diabetic dogs is $30-40 \%$ and is believed to be a contributing factor in the development of diabetes and diabetic ketoacidosis in affected dogs (Watson et al. 2010, Bostrom et al. 2013). The cause and effect relationship of pancreatitis and diabetes in cats is difficult to define. Histological abnormalities consistent with pancreatitis were found in $22-57 \%$ of diabetic cats and in 60 and $67 \%$ of nondiabetic cats (Kraus et al. 1997, Goossens et al. 1998, De Cook et al. 2007, Zini et al. 2012). According to the currently available data and the impression of the authors, pancreatitis is not a frequent cause of diabetes mellitus in cats. Although in principle, severe pancreatitis with extensive tissue destruction may result in damage of the pancreatic islets and $\beta$-cell loss, but unlike dogs this seems to be a rare event in cats. Pancreatitis, however, seems to be a frequent co-morbidity in diabetic cats.

Several endocrinopathies, most notably hypercortisolism (hyperadrenocorticism) in the dog and hypersomatotropism (acromegaly) in the cat cause severe insulin resistance and are frequently diagnosed at the time of or within weeks of establishing the diagnosis of diabetes (Table 1). Similarly, the administration of diabetogenic drugs, most notably glucocorticoids and progestins, may cause glucose intolerance and overt diabetes in dogs and cats that presumably have pre-existing $\beta$-cell defect, islet pathology, or both. Dogs and cats that become euglycemic after correcting for insulin resistance are considered subclinical diabetics.

\section{Gestational diabetes: dogs}

A fourth category in the human classification model is gestational diabetes, which is defined as carbohydrate intolerance with onset or first recognition during pregnancy (ADA 2013). A syndrome resembling gestational diabetes in humans occurs in older female dogs but not in cats. Female dogs ovulate at $\sim 7$-month intervals and serum progesterone concentration is increased for 2 months after ovulation and formation of corpora lutea. Progesterone stimulates growth hormone secretion from the canine mammary gland and both hormones cause insulin resistance and carbohydrate intolerance in the dog (Selman et al. 1992). Older female dogs are frequently diagnosed with diabetes during diestrus or pregnancy when serum progesterone and growth hormone concentrations are increased (Fall et al. 2008a, 2010, Mared et al. 2012). Documenting increased baseline serum insulin concentration supports the presence of functional $\beta$-cells. These dogs presumably have an adequate mass of functional $\beta$-cells to maintain carbohydrate tolerance when insulin resistance is not present (e.g., during periods of ovarian inactivity when progesterone concentrations remain low $(<0.5 \mathrm{ng} / \mathrm{ml}))$, but they are unable to secrete an adequate amount of insulin to maintain euglycemia in the presence of insulin resistance (Fall et al. 2008b). Early recognition and improvement in insulin resistance after ovariectomy, while some $\beta$-cell functions are still present, may reestablish euglycemia without the long-term need for insulin therapy. Failure to quickly correct insulin resistance often results in progressive loss of $\beta$-cells and a greater likelihood for permanent insulin dependency to control hyperglycemia (Fall et al. 2010).

In summary, our current knowledge suggests that the etiological factors involved in the development of diabetes mellitus are similar in dogs, cats, and humans. However, the predominant type of diabetes managed by veterinarians differs between the dog and cat. Immune-mediated diseases are very common in dogs, hence it is not surprising that type 1 diabetes predominates. By contrast, immune-mediated disease is very uncommon in cats and type 1 diabetes is not recognized in this species. Cats have an amyloidogenic amino acid structure of IAPP with the potential to form amyloid depositions within the islets of the pancreas during periods of sustained insulin resistance, as occurs with obesity. Obese cats also develop other derangements that promote the development of

Published by Bioscientifica Ltd 
diabetes; hence type 2 diabetes is predominant in this species. Dogs do not have an amyloidogenic amino acid structure of IAPP and do not develop islet amyloidosis during periods of sustained insulin resistance. This may explain, in part, why type 2 diabetes is not recognized in dogs, even when they are morbidly obese.

\section{Declaration of interest}

The authors declare that there is no conflict of interest that could be perceived as prejudicing the impartiality of the review.

\section{Funding}

This research did not receive any specific grant from any funding agency in the public, commercial or not-for-profit sector.

\section{References}

American Diabetes Association 2013 Standards of medical care in diabetes 2013. Diabetes Care 36 (Suppl 1) S11-S66. (doi:10.2337/dc13-S011)

Andersen MK, Lundgren V, Turunen A, Forsblom C, Iomaa B, Groop PH, Groop L \& Tuomi T 2010 Latent autoimmune diabetes in adults differs genetically from classical type 1 diabetes diagnosed after the age of 35 years. Diabetes Care 33 2062-2064. (doi:10.2337/dc09-2188)

Appleton DJ, Rand JS \& Sunvold GD 2001 Insulin sensitivity decreases with obesity, and lean cats with low insulin sensitivity are at greatest risk of glucose intolerance with weight gain. Journal of Feline Medicine and Surgery 3 211-228. (doi:10.1053/jfms.2001.0138)

Biourge V, Nelson RW, Feldman EC, Willits NH, Morris JG \& Rogers QR 1997 Effect of weight gain and subsequent weight loss on glucose tolerance and insulin response in healthy cats. Journal of Veterinary Internal Medicine 11 86-91. (doi:10.1111/j.1939-1676.1997.tb00078.x)

Bostrom BM, Xenoulis PG, Neioman ST, Pool RR, Fosgate GT \& Steiner JM 2013 Chronic pancreatitis in dogs: a retrospective study of clinical, clinicopathological, and histopathological findings in 61 cases. Veterinary Journal 195 73. (doi:10.1016/j.tvil.2012.06.034)

Brennan CL, Hoenig M \& Ferguson DC 2004 GLUT4 but not GLUT1 expression decreases early in the development of feline obesity. Domestic Animal Endocrinology 26 291-301. (doi:10.1016/j.domaniend. 2003.11.003)

Catchpole B, Adams JP, Holder AL, Short AD, Ollier WE \& Kennedy LJ 2013 Genetics of canine diabetes mellitus: are the diabetes susceptibility genes identified in humans involved in breed susceptibility to diabetes mellitus in dogs? Veterinary Journal 195 139-147. (doi:10.1016/j.tvjl. 2012.11.013)

Costes S, Langen R, Gurlo T, Matveyenko AV \& Butler PC 2013 -cell failure in type 2 diabetes: a case of asking too much of too few? Diabetes 62 327-335. (doi:10.2337/db12-1326)

Davison LJ, Ristic JM, Herrtage ME, Ramsey IK \& Catchpole B 2003 Anti-insulin antibodies in dogs with naturally occurring diabetes mellitus. Veterinary Immunology and Immunopathology 91 53-60. (doi:10.1016/S0165-2427(02)00267-2)

Davison LJ, Weenink SM, Christie MR, Herrtage ME \& Catchpole B 2008 Autoantibodies to GAD65 and IA-2 in canine diabetes mellitus. Veterinary Immunology and Immunopathology 126 83-90. (doi:10.1016/ j.vetimm.2008.06.016)

Davison LJ, Herrtage ME \& Catchpole B 2011 Autoantibodies to recombinant canine proinsulin in canine diabetic patients. Research in Veterinary Science 91 58-63. (doi:10.1016/j.rvsc.2010.08.007)

http://joe.endocrinology-journals.org DOI: $10.1530 / J O E-14-0202$
() 2014 Society for Endocrinology Printed in Great Britain
De Cook HE, Forman MA, Farver TB \& Marks SL 2007 Prevalence and histopathologic characteristics of pancreatitis in cats. Veterinary Pathology 44 39-49. (doi:10.1354/vp.44-1-39)

Donath MY \& Shoelson SE 2011 Type 2 diabetes as an inflammatory disease. Nature Reviews. Immunology 11 98-107. (doi:10.1038/nri2925)

Fall T, Hamlin HH, Hedhammar A, Kämpe O \& von Euler H 2007 Diabetes mellitus in a population of 180,000 insured dogs: incidence, survival, and breed distribution. Journal of Veterinary Internal Medicine $\mathbf{2 1}$ 1209-1216. (doi:10.1111/j.1939-1676.2007.tb01940.x)

Fall T, Johansson Kreuger S, Juberget A, Bergström A \& Hedhammar A 2008 a Gestational diabetes mellitus in 13 dogs. Journal of Veterinary Internal Medicine 22 1296-1300. (doi:10.1111/j.1939-1676.2008. 0199.x)

Fall T, Holm B, Karlsson A, Ahlgren KM, Kämpe O \& Euler H $2008 b$ Glucagon stimulation test for estimating endogenous insulin secretion in dogs. Veterinary Record 163 266-270. (doi:10.1136/vr.163.9.266)

Fall T, Hedhammar A, Wallberg A, Fall N, Ahlgren KM, Hamlin HH, Lindblad-Toh K, Andersson G \& Kämpe O 2010 Diabetes mellitus in Elkhounds is associated with diestrus and pregnancy. Journal of Veterinary Internal Medicine 24 1322-1328. (doi:10.1111/j.1939-1676. 2010.0630.x)

Forcada Y, Holder A, Church DP \& Catchpole B 2014 A polymorphism in the melanocortin 4 receptor gene (MC4R:c.92C $>\mathrm{T}$ ) is associated with diabetes mellitus in overweight domestic shorthaired cats. Journal of Veterinary Internal Medicine 28 458-464. (doi:10.1111/ jvim.12275)

Gerich JE 2002 Is reduced first-phase insulin release the earliest detectable abnormality in individuals destined to develop type 2 diabetes? Diabetes 51(Suppl) S117-S121. (doi:10.2337/diabetes.51.2007.S117)

Goossens MM, Nelson RW, Feldman EC \& Griffey SM 1998 Response to insulin treatment and survival in 104 cats with diabetes mellitus (1985-1995). Journal of Veterinary Internal Medicine 12 1-6. (doi:10.1111/j.1939-1676.1998.tb00489.x)

Guptill L, Glickman L \& Glickman N 2003 Time trends and risk factors for diabetes mellitus in dogs: analysis of veterinary medical data base records (1970-1999). Veterinary Journal 165 240-247. (doi:10.1016/ S1090-0233(02)00242-3)

Haataja L, Gurlo T, Huang CJ \& Butler PC 2008 Islet amyloid in type 2 diabetes, and the toxic oligomer hypothesis. Endocrine Reviews 29 303-316. (doi:10.1210/er.2007-0037)

Hall DG, Kelley LC, Gray ML \& Glaus TM 1997 Lymphocytic inflammation of pancreatic islets in a diabetic cat. Journal of Veterinary Diagnostic Investigation 9 98-100. (doi:10.1177/104063879700900121)

Henson MS, Hegstad-Davies RL, Wang Q, Hardy RM, Armstrong PJ, Jordan K, Johnson KH \& O'Brien TD 2011 Evaluation of plasma islet amyloid polypeptide and serum glucose and insulin concentrations in nondiabetic cats classified by body condition score and in cats with naturally occurring diabetes mellitus. American Journal of Veterinary Research 72 1052-1058. (doi:10.2460/ajvr.72.8.1052)

Hoenig M 2012 The cat as a model for human obesity and diabetes. Journal of Diabetes Science and Technology 6 525-533. (doi:10.1177/ 193229681200600306)

Hoenig M \& Dawe DL 1992 A qualitative assay for $\beta$ cell antibodies. Preliminary results in dogs with diabetes mellitus. Veterinary Immunology and Immunopathology 32 195-203. (doi:10.1016/01652427(92)90046-S)

Hoenig M, Reusch C \& Peterson ME $2000 \beta$ cell and insulin antibodies in treated and untreated diabetic cats. Veterinary Immunology and Immunopathology 77 93-102. (doi:10.1016/S0165-2427(00)00229-4)

Hoenig M, McGoldrick JB, de Beer M, Demaker PN \& Ferguson DC 2006 Activity and tissue-specific expression of lipases and tumor-necrosis factor $\alpha$ in lean and obese cats. Domestic Animal Endocrinology 30 333-344. (doi:10.1016/j.domaniend.2005.09.001)

Hoenig M, Thomaseth K, Waldron M \& Ferguson DC 2007 Insulin sensitivity, fat distribution, and adipocytokine response to different diets in lean and obese cats before and after weight loss. American

Published by Bioscientifica Ltd 
Journal of Physiology. Regulatory, Integrative and Comparative Physiology 292 227-234. (doi:10.1152/ajpregu.00313.2006)

Hull RL, Westermark GT, Westermark P \& Kahn SE 2004 Islet amyloid: a critical entity in the pathogenesis of type 2 diabetes. Journal of Clinical Endocrinology and Metabolism 89 3629-3643. (doi:10.1210/jc. 2004-0405)

Jordan K, Murtaugh MP, O'Brien TD, Westermark P, Betsholtz C \& Johnson KH 1990 Canine IAPP cDNA sequence provides important clues regarding diabetogenesis and amyloidogenesis in type 2 diabetes. Biochemical and Biophysical Research Communications 169 502-508. (doi:10.1016/0006-291X(90)90359-U)

Kennedy LJ, Davison LJ, Barnes A, Short AD, Fretwell N, Jones CA \& Lee AC 2006 Identification of susceptibility and protective major histocompatibility complex haplotypes in canine diabetes mellitus. Tissue Antigens 68 467-476. (doi:10.1111/j.1399-0039.2006.00716.x)

Kharroubi I, Rasschaert TJ, Eizirik DL \& Cnop M 2003 Expression of adiponectin receptors in pancreatic $\beta$ cells. Biochemical and Biophysical Research Communications 312 1118-1122. (doi:10.1016/j.bbrc. 2003.11.042)

Kraus MS, Calvert CA, Jacobs GJ \& Brown J 1997 Feline diabetes mellitus: a retrospective mortality study of 55 cats (1982-1994). Journal of the American Animal Hospital Association 33 107-111.

Lederer R, Rand JS, Jonsson NN, Hughes IP \& Norton JM 2009 Frequency of feline diabetes mellitus and breed predisposition in domestic cats in Australia. Australian Veterinary Journal 179 254-258. (doi:10.1016/ j.tvj1.2007.09.019)

Li S, Shin HJ, Ding EL \& van Dam RM 2009 Adiponectin levels and risk of type 2 diabetes: a systematic review and meta-analysis. Journal of the American Medical Association 302 179-188. (doi:10.1001/jama.2009.976)

Link KR, Allio I, Rand JS \& Eppler E 2013 The effect of experimentally induced chronic hyperglycaemia on serum and pancreatic insulin, pancreatic islet IGF-1 and plasma and urinary ketones in domestic cat (Felis felis). General and Comparative Endocrinology 188 269-281. (doi:10.1016/j.ygcen.2013.04.029)

Mared M, Catchpole B, Kämpe O \& Fall T 2012 Evaluation of circulating concentrations of glucose homeostasis biomarkers, progesterone, and growth hormone in healthy Elkhounds during anestrus and diestrus. American Journal of Veterinary Research 73 242-247. (doi:10.2460/ajvr. 73.2.242)

McCann TM, Simpson KE, Shaw DJ, Butt JA \& Gunn-Moore DA 2007 Feline diabetes mellitus in the UK: the prevalence within an insured cat population and a questionnaire-based putative risk factor analysis. Journal of Feline Medicine and Surgery 9 289-299. (doi:10.1016/j.jfms. 2007.02.001)

Minkus G, Reusch C, Hänichen T, Colbatzky F \& Hermanns W 1991 Pathological changes of the endocrine pancreas in dogs and cats in comparison with clinical data. Tierärztliche Praxis 19 282-289.

Montgomery TM, Nelson RW, Feldman EC \& Polonsky KS 1996 Basal and glucagon-stimulated plasma C-peptide concentrations in healthy dogs, dogs with diabetes mellitus, and dogs with hyperadrenocorticism. Journal of Veterinary Internal Medicine 10 116-122. (doi:10.1111/ j.1939-1676.1996.tb02042.x)

Mori A, Lee P, Takemitsu H, Iwasaki E, Kimura N, Yagishita M, Hayasaka M \& Arai T 2009 Decreased gene expression of insulin signaling genes in insulin sensitive tissues of obese cats. Veterinary Research Communications 33 315-329. (doi:10.1007/s11259-008-9179-y)

Nelson RW, Griffey SM, Feldman EC \& Ford SL 1999 Transient clinical diabetes mellitus in cats: 10 cases (1989-1991). Journal of Veterinary Internal Medicine 13 28-35. (doi:10.1111/j.1939-1676.1999.tb02161.x)

O'Brien TD 2002 Pathogenesis of feline diabetes mellitus. Molecular and Cellular Endocrinology 197 213-219. (doi:10.1016/S0303-7207(02) 00265-4)
O’Brien TD, Westermark P \& Johnson KH 1990 Islet amyloid polypeptide and calcitonin gene-related peptide immunoreactivity in amyloid and tumor cells of canine pancreatic endocrine tumors. Veterinary Pathology 27 194-198. (doi:10.1177/030098589002700307)

Panciera DL, Thomas CB, Eicker SW \& Atkins CE 1990 Epizootiologic patterns of diabetes mellitus in cats: 333 cases (1980-1986). Journal of the American Veterinary Medical Association 197 1504-1508.

Prahl A, Guptill L, Glickman NW, Tetrick M \& Glickman LT 2007 Time trends and risk factors for diabetes mellitus in cats presented to veterinary teaching hospitals. Journal of Feline Medicine and Surgery 9 351-358. (doi:10.1016/j.jfms.2007.02.004)

Radin MJ, Sharkey LC \& Holycross BJ 2009 Adipokines: a review of biological and analytical principles and an update in dogs, cats, and horses. Veterinary Clinical Pathology 38 136-156. (doi:10.1111/ j.1939-165X.2009.00133.x)

Rakatzi I, Mueller H, Ritzeler O, Tennangel N \& Eckel J 2004 Adiponectin counteracts cytokine- and fatty acid-induced apoptosis in the pancreatic $\beta$-cell line INS-1. Diabetologia 47 249-258. (doi:10.1007/ s00125-003-1293-3)

Robertson RP 2009 -cell deterioration during diabetes: what's in the gun? Trends in Endocrinology and Metabolism 20 388-393. (doi:10.1016/j.tem. 2009.05.004)

Scarlett JM \& Donoghue S 1998 Associations between body condition and disease in cats. Journal of the American Veterinary Medical Association 212 1725-1731.

Scheuner D \& Kaufman RJ 2008 The unfolded protein response: a pathway that links insulin demand with $\beta$-cell failure and diabetes. Endocrine Reviews 29 317-333. (doi:10.1210/er.2007-0039)

Selman PJ, Mol JA, Ruttemen GR, Garderen E \& Rijnberk A 1992 Progestininduced growth hormone excess in the dog originates in the mammary gland. Endocrinology 134 287-292. (doi:10.1677/joe.0.1340287)

Slingerland LI, Fazilova VV, Plantinga EA, Kooistra HS \& Beynen AC 2009 Indoor confinement and physical inactivity rather than the proportion of dry food are risk factors in the development of feline type 2 diabetes mellitus. Veterinary Journal 179 247-253. (doi:10.1016/j.tvj1.2007. 08.035)

Verkest KR, Fleeman LM, Rand JS \& Morton JM 2011 $a$ Evaluation of $\beta$-cell sensitivity to glucose and first-phase insulin secretion in obese dogs. American Journal of Veterinary Research 72 357-366. (doi:10.2460/ajvr. 72.3.357)

Verkest KR, Rand JS, Fleeman LM, Morton JM, Richards AA, Rose FJ \& Whitehead JP $2011 b$ Distinct adiponectin profiles might contribute to differences in susceptibility to type 2 diabetes in dogs and humans. Domestic Animal Endocrinology 41 67-73. (doi:10.1016/j.domaniend. 2011.03.003)

Verkest KR, Rand JS, Fleeman LM, Morton JM \& Herrtage ME 2012 Spontaneously obese dogs exhibit greater postprandial glucose, triglyceride, and insulin concentrations than lean dogs. Domestic Animal Endocrinology 42 103-112. (doi:10.1016/j.domaniend.2011. 10.002)

Watson PJ, Archer J, Roulois AJ, Scase TJ \& Herrtage ME 2010 Observational study of 14 cases of chronic pancreatitis in dogs. Veterinary Record 167 968-976. (doi:10.1136/vr.c4912)

Zini E, Osto M, Franchini M, Guscetti F, Donath MY, Perren A, Heller RS, Linscheid P, Bouwman M, Akermann M et al. 2009 Hyperglycaemia but not hyperlipidaemia causes $\beta$ cell dysfunction and $\beta$ cell loss in the domestic cat. Diabetologia 52 336-346. (doi:10.1007/s00125008-1201-y)

Zini E, Lunardi F, Zanetti R, Coppola L, Ackermann M, Lutz TA, Reusch CE \& Cavicchioli L 2012 Histological investigation of endocrine and exocrine pancreas in cats with diabetes mellitus. Journal of Veterinary Internal Medicine 261519 (abstract). (doi:10.1111/jvim.12000)

Received in final form 9 June 2014

Accepted 25 June 2014

Accepted Preprint published online 30 June 2014 http://joe.endocrinology-journals.org

DOI: $10.1530 / \mathrm{JOE}-14-0202$
() 2014 Society for Endocrinology Printed in Great Britain
Published by Bioscientifica Ltd 